\title{
The Role of Lipopeptidophosphoglycan in the Immune Response to Entamoeba histolytica
}

\author{
Isabel Wong-Baeza, ${ }^{1,2}$ Marcela Alcántara-Hernández,, ${ }^{1,2}$ Ismael Mancilla-Herrera, ${ }^{1,3}$ \\ Itzmel Ramírez-Saldívar, ${ }^{1,4}$ Lourdes Arriaga-Pizano, ${ }^{1}$ Eduardo Ferat-Osorio, ${ }^{1,5}$ \\ Constantino López-Macías, ${ }^{1}$ and Armando Isibasi ${ }^{1}$
}

\author{
${ }^{1}$ Medical Research Unit on Immunochemistry, Specialties Hospital, National Medical Centre "Siglo XXI", \\ Mexican Institute for Social Security (IMSS), 06720 Mexico City, Mexico \\ ${ }^{2}$ Graduate Program on Immunology, National School of Biological Sciences, National Polytechnic Institute, 11350 Mexico City, Mexico \\ ${ }^{3}$ Graduate Program on Molecular Biomedicine and Biotechnology, National School of Biological Sciences, \\ National Polytechnic Institute, 11350 Mexico City, Mexico \\ ${ }^{4}$ Graduate Program on Chemical and Biological Sciences, National School of Biological Sciences, National Polytechnic Institute, \\ 11350 Mexico City, Mexico \\ ${ }^{5}$ Gastrointestinal Surgery Department, Specialties Hospital, National Medical Centre "Siglo XXI", \\ Mexican Institute for Social Security (IMSS), 06720 Mexico City, Mexico
}

Correspondence should be addressed to Armando Isibasi, isibasi@prodigy.net.mx

Received 30 June 2009; Accepted 12 October 2009

Academic Editor: Abhay R. Satoskar

Copyright (C) 2010 Isabel Wong-Baeza et al. This is an open access article distributed under the Creative Commons Attribution License, which permits unrestricted use, distribution, and reproduction in any medium, provided the original work is properly cited.

\begin{abstract}
The sensing of Pathogen Associated Molecular Patterns (PAMPs) by innate immune receptors, such as Toll-like receptors (TLRs), is the first step in the inflammatory response to pathogens. Entamoeba histolytica, the etiological agent of amebiasis, has a surface molecule with the characteristics of a PAMP. This molecule, which was termed lipopeptidophosphoglycan (LPPG), is recognized through TLR2 and TLR4 and leads to the release of cytokines from human monocytes, macrophages, and dendritic cells; LPPGactivated dendritic cells have increased expression of costimulatory molecules. LPPG activates NKT cells in a CD1d-dependent manner, and this interaction limits amebic liver abscess development. LPPG also induces antibody production, and anti-LPPG antibodies prevent disease development in animal models of amebiasis. Because LPPG is recognized by both the innate and the adaptive immune system (it is a "Pamptigen"), it may be a good candidate to develop a vaccine against E. histolytica infection and an effective adjuvant.
\end{abstract}

\section{Introduction}

Amebiasis is a disease caused by Entamoeba histolytica, a parasite protozoan that infects humans and is responsible for 40,000 to 110,000 deaths per year [1]. Ten percent of infected persons exhibit clinical symptoms; $80 \%$ to $98 \%$ of these are intestinal, and $2 \%$ to $20 \%$ are extraintestinal. The clinical symptoms can range from a mild and nonspecific presentation (constipation alternated with diarrhea, pain in the lower abdomen, mild nausea during or after meals, and mild abdominal distension with pain in the right iliac fossa) to dysentery, fulminating colitis, and toxic megacolon. Less frequently, amebiasis can cause appendicitis and ameboma.
Amebic liver abscess is the most frequent presentation of invasive extraintestinal amebiasis, but the lungs, heart, brain, skin, and genitals can also be affected [2].

Approximately 500 million people in the world are currently infected with $E$. histolytica [1]. The incidence of amebiasis has decreased significantly in recent years because of increased sanitation in many countries and the use of effective therapeutic agents. The World Health Organization and the Pan-American Health Organization recommend the treatment of all patients with confirmed E. histolytica infection, regardless of the presence of symptoms. The treatments of choice for asymptomatic intestinal amebiasis are the luminal amebicides paromomycin sulfate and diloxanide 
furoate. Symptomatic intestinal or extraintestinal infection is treated with metronidazole in combination with a luminal amebicide. Nitazoxanide is an effective luminal amebicide, and it is also effective for invasive amebiasis. Gastrointestinal complications, such as perforation, intestinal obstruction, and toxic megacolon, are treated with surgery. Most hepatic abscesses respond to metronidazole, but if they do not, they can be aspirated by puncture or treated with open surgery [3-5].

In spite of the effective therapeutic agents that are available for the treatment of amebiasis, it still constitutes a global health problem [6]. The prevalence of amebiasis varies from $1 \%$ in industrialized countries to $50 \%-80 \%$ in tropical countries [7-10].

\section{Identification of Lipopeptidophosphoglycan}

In the 1970s, amebiasis was the fourth most frequent infectious disease in Mexico, with an incidence of 118.9 per 10,000 inhabitants (almost 1500 times higher than the incidence in the United States in the same year) [11]. This situation prompted many researchers to study several aspects of this parasitic disease, including comparative studies of drugs for the treatment of acute amebic liver abscess [12] and various studies of seroepidemiology of amebiasis in adults [13-17].

Several genes from E. histolytica were cloned, sequenced and expressed in an effort to identify new drug targets for this parasite, including the alcohol dehydrogenase gene (Ehadh3) [18], the ferredoxin oxidoreductase gene [19], the EhDEAD1 RNA helicase gene [20], and the Ehvma2 gene (which encodes the B subunit of the vacuolar ATPase) [21]. Mechanisms of drug resistance in E. histolytica were also studied, and it was determined that the multidrugresistant phenotype is regulated at the transcriptional level by the P-glycoprotein-like genes (EhPgp) 1 and 5 [22]. A protein complex (EhCPADH) was identified on the surface of E. histolytica. This complex is formed by a cysteine proteinase that digests gelatin, collagen type I, fibronectin and hemoglobin (EhCP112), and an adhesin (EhADH112), and is involved in adherence, phagocytosis, and cytolysis [23, 24]. Polypeptides derived from this complex were assessed as vaccine candidates, and it was demonstrated that they confer partial protection from amebic liver abscess in hamsters (Mesocricetus auratus) [25].

The role of the immune response in the pathogenesis of amebiasis was also studied; the early approaches demonstrated that serum from infected patients could neutralize the virulence of E. histolytica cultures [26] and that this serum could confer antiameba passive immunity in hamsters [27]. The importance of cellular immunity in the control of amebiasis was addressed in several studies, which demonstrated the ability of activated eosinophils to kill the parasite in vitro [28] and to protect from amebic liver abscess in vivo [29], and the killing of trophozoites by peritoneal macrophages in hamsters [30] and by activated $\mathrm{T}$ lymphocytes and macrophages in humans [31]. It was shown that patients cured from amebic liver abscess had specific T lymphocytes that killed trophozoites in vitro [31].
It was also demonstrated that molecules from E. histolytica were able modulate the host immune response. The supernatant fluid of axenically grown E. histolytica could inhibit chemotaxis and random mobility of human monocytes, without affecting the locomotion of neutrophils [32]. The effect was attributed to a monocyte locomotion inhibitory factor (MLIF), and physicochemical analysis revealed that MLIF is a heat-stable pentapeptide (Met-Gln-Cys-Asn-Ser) that inhibits locomotion of monocytes, respiratory burst of monocytes and neutrophils, and delayed hypersensitivity skin reactions to dinitrochlorobenzene in guinea pigs (Cavia porcellus) [33]. MLIF decreased the expression of macrophage inflammatory protein- (MIP-) 1alpha, MIP1beta, and chemokine receptor CCR1 in a phorbol myristate acetate- (PMA-) stimulated human monocyte cell line, which suggests that the inhibition of monocyte locomotion could be attributed to downregulation of chemokines and chemokine receptors [34]. MLIF also decreased interleukin(IL-) 1beta and increased IL-10 production by PMAstimulated human CD4 T lymphocytes [35]. Immunization with a tetramer of MLIF around a lysine core completely protected gerbils (Meriones unguiculatus) against amebic liver abscess [36].

In 1969, Galanos et al. developed a new method for the extraction of bacterial lipopolysaccharide (LPS, Figure 1(a)) [37] and, in the following years, many of the chemical, biological, and immunological properties of the so-called endotoxin were determined [38-44]. LPS is a major structural component of the outer membrane of Gram-negative bacteria; it activates many cell types, induces inflammation, and produces fever and shock. We decided to determine if E. histolytica had a surface molecule with chemical and immunological properties similar to those of bacterial LPS. The use of a modified phenol-water extraction procedure on E. histolytica trophozoites yielded a molecule with $85 \%$ carbohydrate, $8 \%$ peptide, $2.5 \%$ lipid, and $1 \%$ phosphate, which was termed lipopeptidophosphoglycan (LPPG, Figure 1(c)) $[45,46]$. The isolation and structural characterization of microbial molecules can lead to the identification of new drug targets and new antigens that are recognized by the immune system; some antigens are good candidates for vaccine development. LPPG was first identified as an antigen; antiameba IgG antibodies were detected in rats after intracecal inoculation of trophozoites [47], antiLPPG IgA antibodies were found in colostrum of healthy volunteers [48], and antiameba plasma cells were found in peripheral blood of patients with amebic liver abscess [49]. Monoclonal antiproteophosphoglycan antibodies were described by several groups [50-53]. However, as research in immunology progressed, LPPG was studied as a molecule that could be sensed not only by the adaptive immune system but also by the innate immune system.

\section{Sensing of Parasites by the Immune System}

The relevance of adaptive immunity (whose main effectors are $\mathrm{T}$ and $\mathrm{B}$ lymphocytes) in protection against infections was well recognized in the last decades of the past century, while the role of neutrophils, monocytes, macrophages, and 

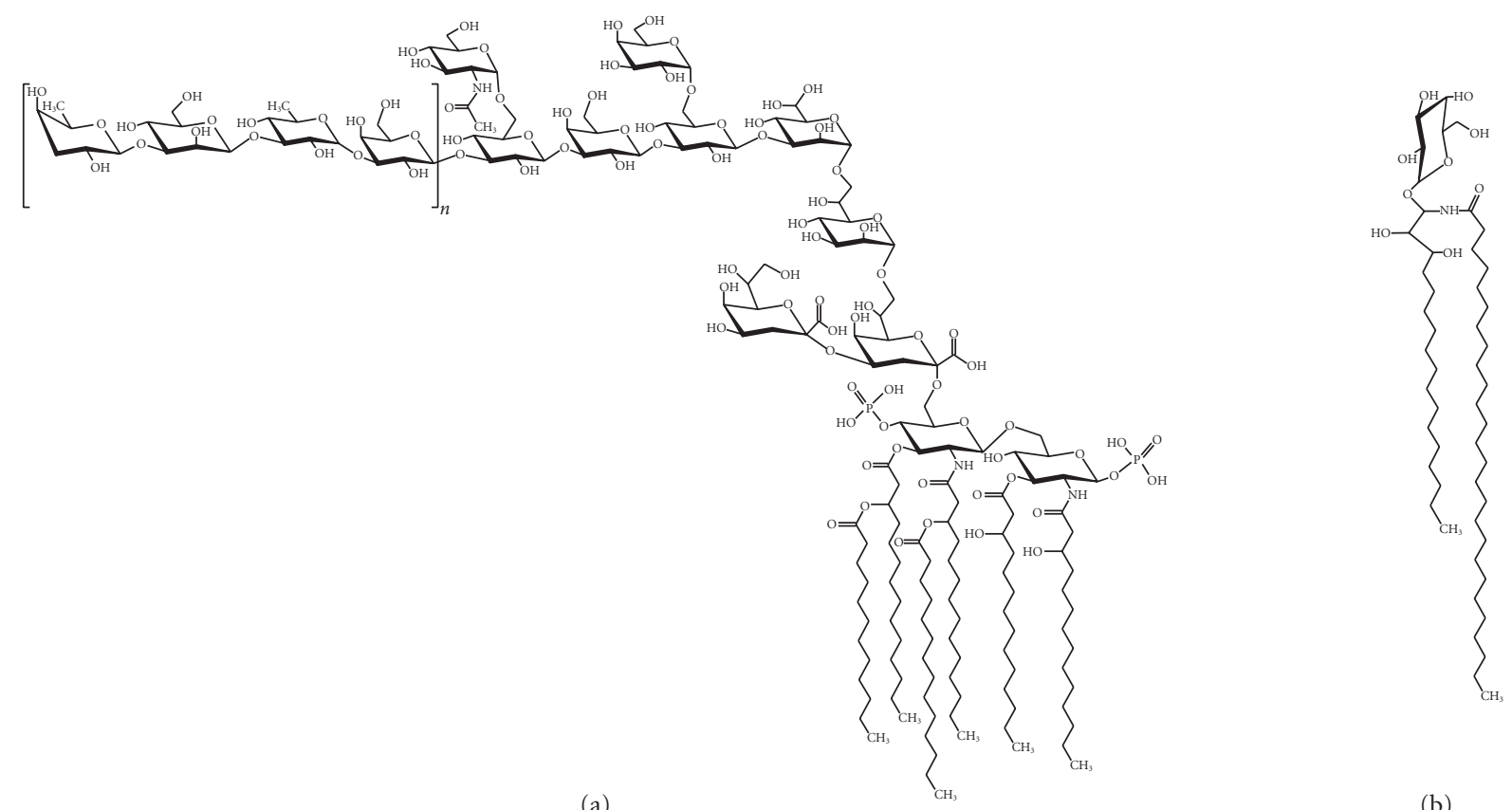

(a)

(b)

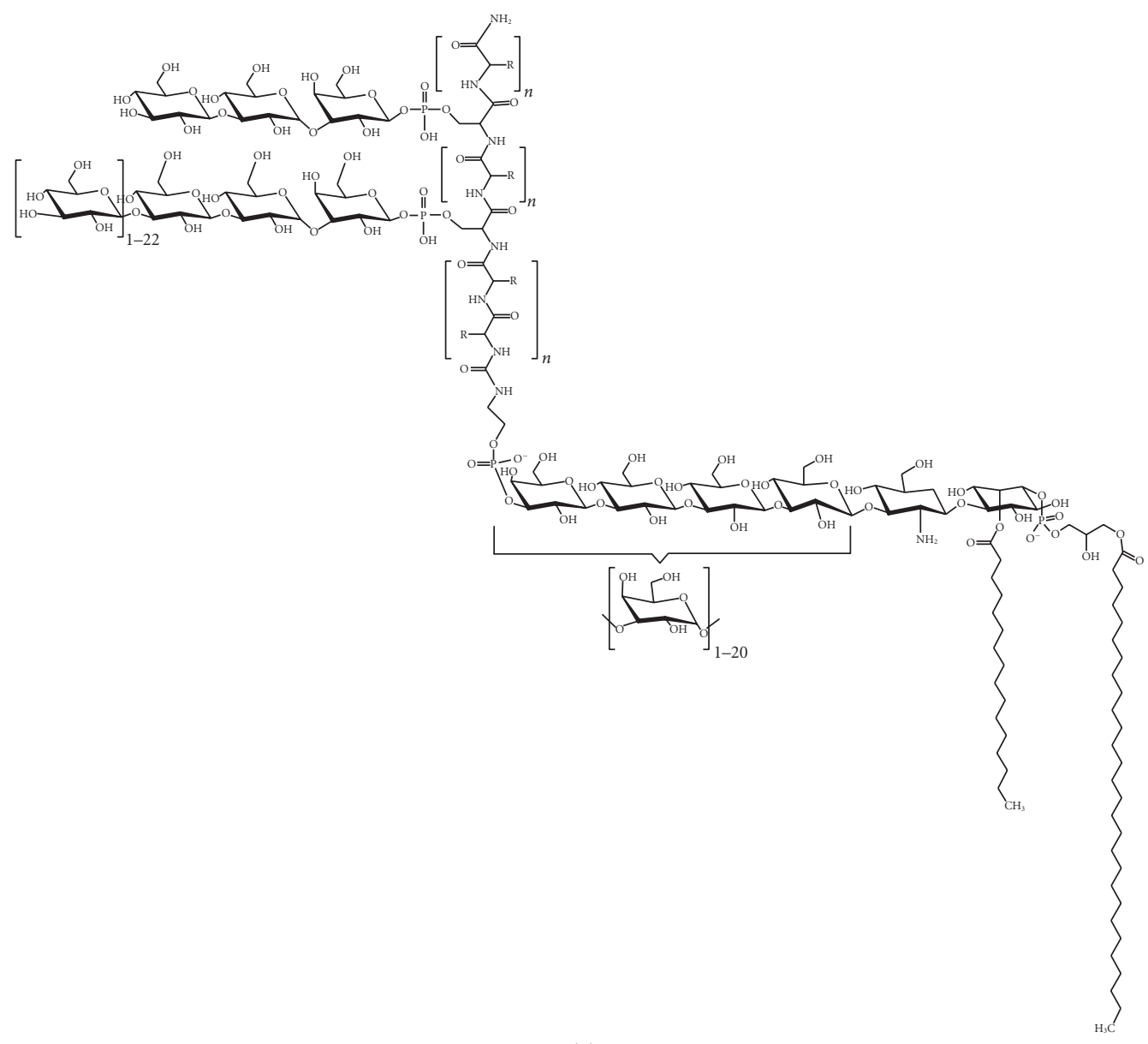

(c)

FIGURE 1: (a) Lipopolysaccharide (LPS) from the Gram-negative bacterium Escherichia coli is the most potent activator of TLR4 [54]. (b) Alpha-galactosyl ceramide from the marine sponge Agelas mauritanius is presented via CD1d and activates NKT cells [55]. (c) Partial structure of lipopeptidophosphoglycan (LPPG) from Entamoeba histolytica of the HM1: IMSS strain, which was originally isolated from a patient with liver abscess $[56,57]$. The structure of the active phosphoinositol moiety of LPPG was characterized in [58]. 
other cells of the innate immune system was seen as a that of a "first line of defense" that contained infections until adaptive immunity was fully activated. It was known that LPS, a component of the outer membrane of Gram-negative bacteria, caused fever and shock in animal models and that it induced the secretion of proinflammatory cytokines by monocytes, macrophages, and epithelial cells. However, the receptor that sensed LPS remained elusive. Many phagocytic receptors on macrophages had been described, but none of these was responsible for the biological properties of LPS [59].

Two strains of mice, $\mathrm{C} 3 \mathrm{H} / \mathrm{HeJ}$ and $\mathrm{C} 57 \mathrm{BL} / 10 \mathrm{ScCr}$, which were resistant to endotoxic shock, were identified $[60,61]$. In 1998, the positional cloning of the affected locus in $\mathrm{C} 3 \mathrm{H} / \mathrm{HeJ}$ mice showed a point mutation in Toll-like receptor (TLR) 4, a previously orphan receptor, and C57BL/10ScCr mouse were found to lack TLR4 [62]. TLR4 is a member of a family of proteins that share a signaling domain (TIR) with IL-1 receptor and are related to the Toll proteins of the fruit fly, Drosophila. Toll was described in 1988 as a transmembrane protein that is required for establishing the embryonic dorsal-ventral pattern in flies [63]. In 1996, Toll was shown to be critical for the antifungal response in Drosophila [64], and it was suspected that the human homologues of Toll, which were described in 1998 [65], would be relevant for the immune response in humans. Indeed, it was found that a constitutively active mutant of human TLR4, transfected into a monocytic cell line, could induce the activation of NF-kappaB and the expression of the proinflammatory cytokines IL-1, IL-6, and IL- 8 as well as the expression of the costimulatory molecule CD80 (B7.1), which is required for the activation of naïve $\mathrm{T}$ lymphocytes [66]. After the establishment of TLR4 as the main sensor for LPS in mice, it was immediately suggested that other members of the Toll family in mammals could also serve as sensors for microbial molecules. Many molecules of bacteria, viruses, and fungi, and others that are found during viral replication, have been identified as agonists of mammalian TLRs (Table 1) $[67,68]$. The study of TLRs and other innate receptors has established innate immunity not only as a first line of defense against infections but also as a critical component of the immune system that induces and regulates the adaptive response [69].

The molecules that are sensed by TLRs are widely distributed among groups of microorganisms, and they are essential for the metabolism or the structural integrity of the microbe, so they are highly conserved in evolution. These molecules were termed pathogen-associated molecular patterns (PAMPs) [70], although their expression is not restricted to pathogens, and this term is used widely to this day. Several molecules from protozoan and helminth parasites were also identified as PAMPs [71] (Table 2). In protozoan parasites, many surface molecules are linked to glycosylphosphatidylinositol (GPI), which is inserted in the plasma membrane. GPI-anchored molecules include lipophosphoglycan (LPG) and LPPG; they are essential for survival and virulence of the parasite, and they are likely the major macromolecules on the trophozoite surface [72]. In Leishmania, LPG is involved in intestinal adhesion and
TABLE 1: Some TLR agonists from bacteria, viruses, and fungi (modified from $[67,68]$ ).

\begin{tabular}{lcc}
\hline TLR & Microbial ligand & Source \\
\hline TLR1/TLR2 & $\begin{array}{c}\text { Triacyl lipopeptides } \\
\text { Lipoarabinomannan }\end{array}$ & $\begin{array}{c}\text { Bacteria } \\
\text { Mycobacteria }\end{array}$ \\
\hline TLR2 & Peptidoglycan & Porins \\
& Lipoteichoic acid & Zymosan \\
& Diacyl lipopeptides & Gram-positive bacteria \\
TLR2/TLR6 & dsRNA & Fungi \\
\hline TLR3 & LPS & Mycoplasma \\
\hline TLR4 & Porins & Gram-negative bacteria \\
& Respiratory syncytial & Respiratory syncytial virus \\
& virus fusion protein & Bacteria \\
\hline TLR5 & Flagellin & Virus \\
\hline TLR7 & ssRNA & Virus \\
\hline TLR8 & ssRNA & Bacteria, virus \\
\hline TLR9 & CpG DNA & Uropathogenic bacteria \\
\hline TLR11 & - &
\end{tabular}

resistance to insect hydrolases; LPG-deficient strains are unable to survive in their vector. Leishmania LPG gains phosphosaccharide domains as procyclic promastigotes in the vector midgut differentiate to infectious metacyclic promastigotes; this structural change in LPG mediates detachment from vector midgut and acquisition of complement resistance [73]. LPG also induces the production of nitric oxide and proinflammatory cytokines by macrophages in the host [74]. LPG from metacyclic promastigotes is a more effective activator of TLR2 in NK cells than LPG from procyclic promastigotes [75].

Plasmodium GPI-anchored molecules are required for the induction of proinflammatory responses, which promote pathogenesis [76]. However, activation of innate and adaptive immune responses is necessary to control parasite growth and frequent $t l r 4$ polymorphisms predispose African children to severe malaria [77]. Therefore, it is proposed that overactivation or deregulation of the inflammatory response is the cause of the pathological condition [78, 79]. Several mucin-like GPI-anchored glycoproteins have been isolated from the Trypanosoma cruzi surface. A T. cruzi trans-sialidase adds sialic acid residues to these molecules, which are required for survival and infectivity $[72,80]$. GPI-anchored molecules purified from $T$. cruzi trypomastigotes signal through TLR2 and induce the production of IL-12, tumor necrosis factor (TNF)-alpha and nitric oxide by murine macrophages [81]; signaling through TLR2 synergizes with TLR9 and is crucial to control the infection [82]. Tc52 is a soluble molecule that is released by $T$. cruzi during parasitemia, and it activates macrophages and dendritic cells via TLR2 [83]. GPI-anchored molecules isolated from Toxoplasma activate TLR4, while glycan cores and phospholipid moieties from these molecules activate both TLR2 and TLR4 [84]. Lysophosphatidylserine-containing lipids from 
TABLE 2: TLR agonists from protozoan and helminth parasites.

\begin{tabular}{|c|c|c|c|}
\hline TLR & Parasite ligand & Source & Reference \\
\hline \multirow{9}{*}{ TLR2 } & Lipopeptidophosphoglycan & Entamoeba histolytica (trophozoite) & {$[85]$} \\
\hline & Glycosylphosphatidylinositol & Plasmodium falciparum (merozoite) & {$[76]$} \\
\hline & & Toxoplasma gondii (tachyzoite) & {$[84]$} \\
\hline & Glycoinositol phospholipid & Plasmodium falciparum (merozoite) & [76] \\
\hline & & Toxoplasma gondii (tachyzoite) & [86] \\
\hline & Lysophosphatidylserine & Schistosoma mansoni (egg and adult worm) & [87] \\
\hline & Lipophosphoglycan & Leishmania major (promastigote) & [74] \\
\hline & $\begin{array}{l}\text { Glycosylphosphatidylinositol with } \\
\text { unsaturated alkyl-glycerol }\end{array}$ & Trypanosoma cruzi (trypomastigote) & {$[81]$} \\
\hline & Tc52 & Trypanosoma cruzi (epimastigote) & [83] \\
\hline TLR2/TLR6 & Glycosylphosphatidylinositol & Plasmodium falciparum (schizont) & {$[78]$} \\
\hline \multirow{8}{*}{ TLR4 } & Lipopeptidophosphoglycan & Entamoeba histolytica (trophozoite) & {$[85]$} \\
\hline & Glycoinositol phospholipid with ceramides & Trypanosoma cruzi (epimastigote) & [88] \\
\hline & Glycosylphosphatidylinositol & Plasmodium falciparum (merozoite) & {$[76]$} \\
\hline & & Toxoplasma gondii (tachyzoite) & {$[84]$} \\
\hline & Glycoinositol phospholipid & Plasmodium falciparum (merozoite) & {$[76]$} \\
\hline & & Toxoplasma gondii (tachyzoite) & {$[86]$} \\
\hline & Phosphorylcholine & Filarial nematode & [89] \\
\hline & Lacto- $N$-fucopentaose III & Schistosoma mansoni & [90] \\
\hline \multirow{5}{*}{ TLR9 } & Hemozoin & Plasmodium falciparum & [91] \\
\hline & DNA & Trypanosoma brucei & {$[92]$} \\
\hline & & Trypanosoma cruzi & {$[92]$} \\
\hline & & Leishmania major & [93] \\
\hline & & Entamoeba histolytica & [94] \\
\hline TLR11 & Profilin-like molecule & Toxoplasma gondii & [95] \\
\hline
\end{tabular}

Schistosoma mansoni induce the maturation of dendritic cells that prime Th2 and regulatory $\mathrm{T}$ cell responses, which favor the establishment of chronic infections with little tissue damage [87].

\section{Function of LPPG as a PAMP and Role of Inflammation in the Pathogenesis of Amebiasis}

The similarities in chemical structure between LPS and LPPG (Figures 1(a) and 1(c)), and the presence of a GPI anchor in LPPG, suggested that LPPG might be a PAMP. This would explain how the innate immune system senses the presence of E. histolytica, an event that is necessary for the orchestration of the inflammatory response in amebiasis. Studies from our laboratory demonstrated that LPPG is recognized through TLR2 and TLR4. Human embryonic kidney- (HEK-) 293 cells were rendered LPPG responsive through overexpression of TLR2 or TLR4/MD2. Coexpression of CD14 enhanced LPPG signal transmission through TLR2 and TLR4. The interaction of LPPG with TLR2 and TLR4 resulted in activation of NF-kappaB and release of IL-8, IL-10, IL-12p40, and TNF-alpha from human monocytes $[85,96]$. Human macrophages and dendritic cells internalize LPPG. As shown by colocalization of LPPG with late endosomes marked with fluorescein isothiocyanate-dextran and LAMP-1, the internalization process involves intracellular traffic from the cell membrane to late endosomes. LPPG-activated dendritic cells have increased expression of costimulatory molecules CD80, CD86, and CD40 and produce TNF-alpha, IL-8, and IL-12 [97]. These results show that LPPG activates antigenpresenting cells and reaches intracellular compartments that are involved in antigen presentation. Responsiveness of mouse macrophages lacking TLR2 expression (TLR2-/-) or functional TLR4 $(\mathrm{C} 3 \mathrm{H} / \mathrm{HeJ})$ to LPPG challenge was impaired, while macrophages from $\mathrm{C} 3 \mathrm{H} / \mathrm{HeJ} / \mathrm{TLR} 2-/-$ mice were unresponsive. In contrast to wild-type and TLR2-/mice, which succumbed to LPPG-induced shock, $\mathrm{C} 3 \mathrm{H} / \mathrm{HeJ}$ mice were resistant [85]. All these results clearly establish that LPPG is a PAMP from E. histolytica that induces the activation of innate immunity.

In humans, the pathogenesis of E. histolytica requires adhesion of trophozoites to the host cells, phagocytosis of host cells and bacteria by trophozoites, and tissue destruction by amebic enzymes and by enzymes released from lysed neutrophils. The adhesion of trophozoites to host cells is required for tissue invasion; this adhesion is mediated, in part, by a galactose/N-acetylgalactosamine- (Gal/GalNAc-) binding lectin, which is also cytotoxic and confers protection from complement. Other important adhesins are a $220 \mathrm{kDa}$ cell surface protein, a $112 \mathrm{kDa}$ adhesin (EhADH112), and 
a surface LPG [23, 98-100]. Phagocytosis is regulated by adhesins and by signaling pathways that control cytoskeleton structure and vesicular traffic. A phagosome-associated transmembrane kinase (PATMK) binds to phosphatidylserine on host cells and initiates their phagocytosis by trophozoites [101]. Trophozoites cause damage of host cells and extracellular matrix through the action of amebapore, amebic phospholipases, and proteolytic enzymes (cysteine endopeptidases, cysteine proteinase, acid and neutral proteinases, collagenases, histolysin, amebapain, cathepsin B) [102-108]. Neutrophils are the first cells that infiltrate the necrotic lesions caused by E. histolytica in the intestine and liver [109-113], where they are killed by trophozoites. The enzymes and reactive oxygen species released from these neutrophils increase tissue damage, and in this context, LPPG could be seen as a virulence factor that promotes tissue invasion by causing inflammatory damage to host cells. However, the role of inflammation in amebiasis is still controversial [114]: in susceptible animals (hamsters and gerbils) inflammation is related to host cell lysis and facilitates the spreading of trophozoites [115], while in resistant animals (mice, guinea pigs), inflammatory cells protect the host by killing trophozoites $[116,117]$.

E. histolytica genomic DNA is recognized by TLR9 and induces the production of TNF-alpha by a macrophage cell line [94], and Gal/GalNAc-binding lectin activates NF-kappaB and mitogen-activated protein (MAP) kinases in macrophages. These transcription factors increase the expression of several genes, including TLR2 [118]. It is likely that genomic DNA and Gal/GalNAc-binding lectin, along with LPPG, contribute to the initiation of inflammation in response to E. histolytica.

Silencing of the expression of E. histolytica GPI-anchored molecules by antisense RNA-mediated inhibition of their biosynthetic pathways suppresses endocytosis, adhesion, and proliferation of the trophozoites [119]. Specific blockade of LPG and LPPG by monoclonal antibody EH5 reduces intestinal inflammation and tissue damage in a severe combined immunodeficient (SCID) mouse model of intestinal amebiasis with human intestine xenograft [120]. EH5 also prevents liver abscess development in an SCID mouse model [52] and E. histolytica adhesion and cytotoxicity to a hamster cell line [101]. These results suggest that LPPG is a virulence factor of E. histolytica. Mirelman and colleagues found that a nonvirulent $E$. histolytica strain had reduced expression of LPG and LPPG; they also found no LPG and a modified LPPG (with a higher negative charge and different lengths of oligosaccharide chains) in the low-virulence strain Rahman and in the nonpathogenic Entamoeba dispar [121].

Recently, a role for LPPG in protection against invasive amebiasis was shown. The chemical structure of LPPG has some similarities with alpha-galactosyl ceramide, a known activator of NKT cells [55] (Figures 1(b) and 1(c)). NKT cells share many surface receptors with natural killer (NK) cells and, like conventional T cells, express $\mathrm{T}$ cell receptors that are generated by somatic DNA rearrangement. However, most NKT cells express semi-invariant $\mathrm{T}$ cell receptors, consisting of $\mathrm{V} \alpha 14-\mathrm{J} \alpha 18 / \mathrm{V} \beta 8.2$ chains in mouse and $\mathrm{V} \alpha 24-\mathrm{J} \alpha 18 / \mathrm{V} \beta 11$ chains in humans [122]. This limited repertoire, conserved between individuals and presumably selected by evolution, is more closely related to the pattern-recognition receptors of innate immunity than to the highly diverse receptors of adaptive immunity. NKT cells recognize glycolipid antigens presented by nonpolymorphic CD1d molecules; these glycolipids can be endogenous, like lysosomal isoglobotrihexosyl ceramide [123], and exogenous, like glycosyl ceramides from Gram-negative, LPS-negative Sphingomonas capsulata [124]. In a mouse model, it was demonstrated that NKT cells play a central role in the control of amebic liver abscess caused by E. histolytica. Specific activation of NKT cells by alpha-galactosyl ceramide or LPPG induced significant protection, while CD1d-/- mice suffered from severe abscess development [58]. The phosphoinositol moiety of LPPG was shown to induce interferon- (IFN-) gamma but not IL-4 secretion in NKT cells. NKT cell activation was dependent on the presence of CD1d and simultaneous TLR receptor signaling, as indicated by the absence of IFN-gamma secretion in antigen-presenting cells from TLR2- or TLR6deficient mice [58]. These results suggest that NKT cell activation by LPPG is important to limit amebic liver abscess development and may help to explain why the vast majority of E. histolytica-infected individuals do not develop invasive amebiasis.

\section{LPPG as a Molecule That Is Sensed by Both the Innate and the Adaptive Immune Systems}

Molecules that are recognized by receptors of both innate and adaptive immune systems are, in general, highly immunogenic; we have referred to these molecules as "Pamptigens" $[125,126]$. Some examples of molecules that present this dual recognition include porins, profilin, polysaccharide A, yellow fever vaccine, and respiratory syncytial virus vaccine. Salmonella typhi porins are recognized by TLR2 and TLR4 [126], and they induce high antibody titers that persist during the whole lifetime of mice [127]. Toxoplasma gondii profilin, a TLR11 agonist, is an immunodominant antigen in the CD4+ T cell response to the pathogen [128]. Bacteroides fragilis polysaccharide A activates CD4+ T cells by a mechanism that depends on TLR2 signaling and antigen presentation by the MHCII pathway [129]. Live attenuated yellow fever vaccine $17 \mathrm{D}$, one of the most effective vaccines available, activates TLR2, 7, 8, and 9 and induces antigenspecific CD8+ T cells [130]. Poor TLR signaling by a formalin-inactivated respiratory syncytial virus vaccine led to the induction of low-affinity antibodies and to the failure of the vaccine to protect immunized children [131].

Molecules that are recognized by innate and adaptive receptors of the immune system are also effective adjuvants. Innate immunity participates in the induction and regulation of adaptive responses; without adjuvants, molecules that are recognized by adaptive receptors but not by innate receptors fail to elicit antibody or $\mathrm{T}$ cell responses. Antigen recognition alone is not sufficient to activate adaptive immune responses, and innate signals are required to indicate the microbial origin of the antigen; adjuvants provide this signal by activating innate immune receptors $[132,133]$. 


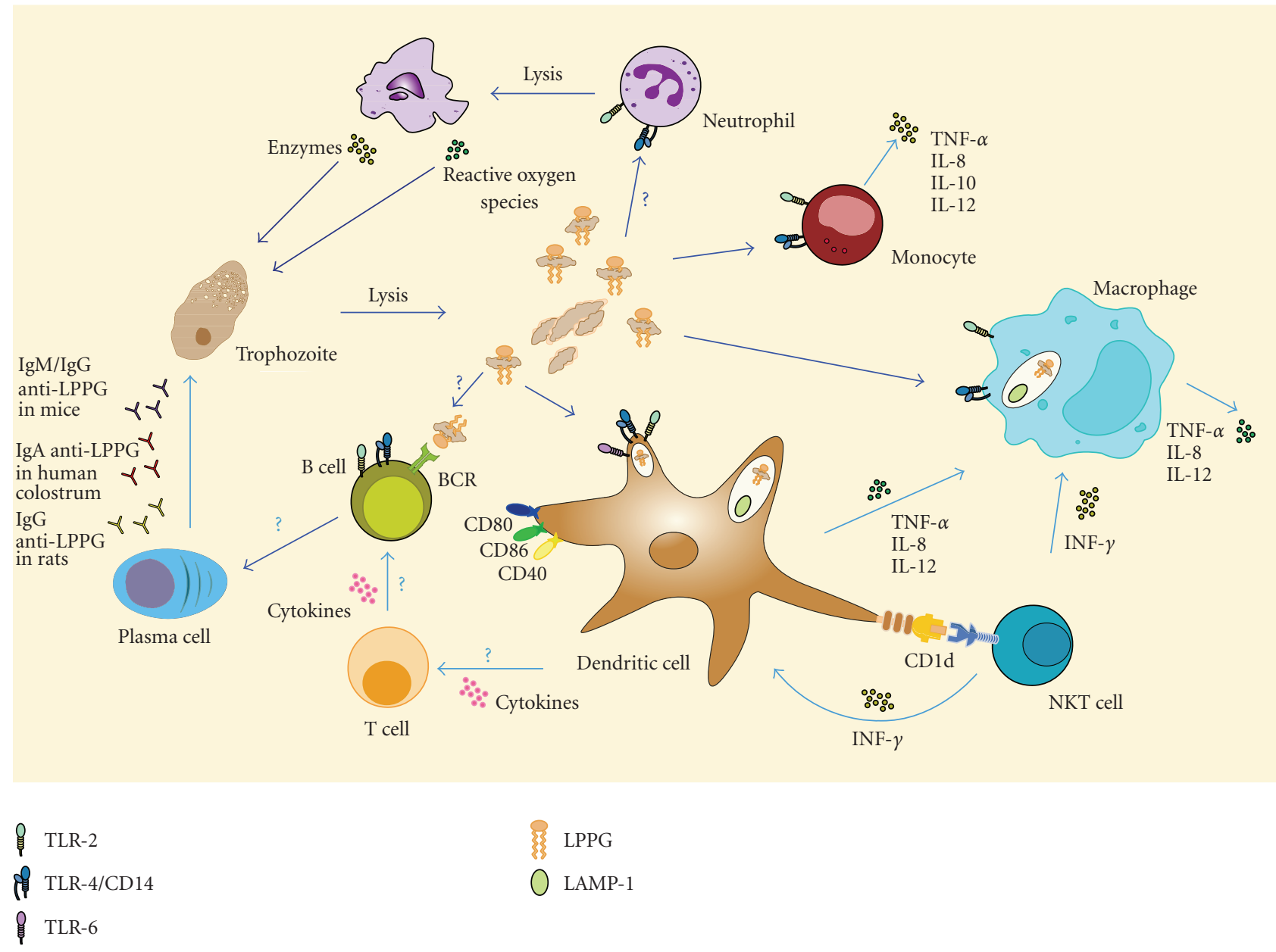

FIgURE 2: The role of lipopeptidophosphoglycan (LPPG) in the immune response to Entamoeba histolytica. During E. histolytica infection, amebic enzymes and enzymes and reactive oxygen species from neutrophils cause tissue damage. LPPG released from lysed trophozoites is recognized through TLR2 and TLR4/CD14 and induces the production of IL-8, IL-10, IL-12p40, and TNF-alpha by monocytes [85, 96]. Macrophages and dendritic cells internalize LPPG into LAMP-1+ endosomes, and LPPG-activated dendritic cells have increased expression of costimulatory molecules CD80, CD86, and CD40 and produce TNF-alpha, IL-8, and IL-12 [97]. NKT cells are also activated by LPPG, and this depends on the presence of CD1d on dendritic cells and simultaneous TLR2 and TLR6 signaling [58]. Anti-LPPG antibodies have been described in humans and in animal models [47-53]. The mechanism that leads to the production of these antibodies has not been determined, but it is probably influenced by the innate signaling of LPPG on dendritic cells and B cells.

LPPG signals through TLR2 and TLR4, and it induces the production of IFN-gamma (a cytokine that activates macrophages and increases cytotoxic $\mathrm{T}$ cell responses) by NKT cells. LPPG is also an antigen, because anti-LPPG antibodies have been detected in animal models and in patients with amebiasis. The mechanism that leads to the production of these antibodies has not been determined, but it is probably influenced by the innate signaling of LPPG (Figure 2). The intrinsic immunogenicity of LPPG and the fact that it is a virulence factor of E. histolytica make LPPG an attractive candidate for vaccine development. Its properties as an adjuvant also deserve further study.

\section{Concluding Remarks}

The study of E. histolytica was initially motivated by the high morbidity and mortality of amebiasis, and in our group, this research led to the identification of LPPG, one of the first PAMPs described in parasites, and a promising vaccine candidate and potential adjuvant. The incidence and severity of amebiasis has declined, because of improved sanitation and effective treatments, but this disease is still a health problem in many parts of the world. The development of a vaccine that effectively protects against $E$. histolytica infection would have a positive impact on global health.

\section{Abbreviations \\ Gal/GalNAc: Galactose/N-acetylgalactosamine \\ GPI: $\quad$ Glycosylphosphatidylinositol \\ IFN: Interferon \\ IL: $\quad$ Interleukin \\ MAP kinases: Mitogen-activated protein kinases}


LAMP: Lysosome-associated membrane glycoprotein

LPG: Lipophosphoglycan

LPPG: Lipopeptidophosphoglycan

LPS: Lipopolysaccharide

MHCII: Major histocompatibility complex class II

MIP: Macrophage inflammatory protein

MLIF: Monocyte locomotion inhibitory factor

NK: Natural killer

PAMP: Pathogen associated molecular pattern

PATMK: Phagosome-associated transmembrane kinase

PMA: Phorbol myristate acetate

SCID: Severe combined immunodeficiency

TLR: Toll-like receptor

TNF: Tumor necrosis factor.

\section{Acknowledgments}

I. Wong-Baeza, M. Alcántara-Hernández, I. MancillaHerrera, and I. Ramírez-Saldívar received scholarships from Consejo Nacional de Ciencia y Tecnología (CONACyT) and IMSS. The authors thank Omar Agni García-Hernández for assistance in the preparation of Figure 2.

\section{References}

[1] J. Araujo, M. E. García, O. Diaz-Suárez, and H. Urdaneta, "Amebiasis: importance of the diagnosis and treatment. Minireview," Investigación Clínica, vol. 49, no. 2, pp. 265-271, 2008.

[2] G. A. Nari, E. R. Ceballos, G. Carrera Ladrón, et al., "Amebic liver abscess. Three years experience," Revista Española de Enfermedades Digestivas, vol. 100, no. 5, pp. 268-272, 2008.

[3] R. Graillet, M. Sánchez Aguilar, A. O. Morán-Mendoza, J. F. Hernández-Sierra, A. Gordillo-Moscoso, and J. H. TapiaPérez, "Analysis of factors associated to failure of medical treatment of amoebic liver abscess," Cirugía Española, vol. 84, no. 2, pp. 83-86, 2008.

[4] R. Khan, S. Hamid, S. Abid, et al., "Predictive factors for early aspiration in liver abscess," World Journal of Gastroenterology, vol. 14, no. 13, pp. 2089-2093, 2008.

[5] B. S. Pritt and G. C. Clark, "Amebiasis," Mayo Clinic Proceedings, vol. 83, no. 10, pp. 1154-1160, 2008.

[6] S. L. Stanley Jr., "Amoebiasis," The Lancet, vol. 361, no. 9362, pp. 1025-1034, 2003.

[7] J. Araujo, M. García, O. Díaz-Suárez, et al., "Amebiasis: relevance of its diagnosis and treatment," Investigación Clínica, vol. 49, no. 2, pp. 265-271, 2008.

[8] D. S. Blanc, "Determination of taxonomic status of pathogenic and nonpathogenic Entamoeba histolytica zymodemes using isoenzyme analysis," Journal of Protozoology, vol. 39, no. 4, pp. 471-479, 1992.

[9] D. A. Bruckner, "Amebiasis," Clinical Microbiology Reviews, vol. 5, no. 4, pp. 356-369, 1992.

[10] Mexican Secretary of Health, "Epidemiological Survey, week 12. Cases per federal entity of infectious and parasitic diseases of the digestive apparatus, until week 12, 2009," Mexico, May 2009, http://www.dgepi.salud.gob.mx/boletin/2009/sem13/ pdf/cua4.3.pdf.
[11] L. Ávalos-Chávez, “Amebiasis," in Pediatry, L. ÁvalosChávez, X. Ávalos-Huízar, and L. Ávalos-Huízar, Eds., Jalisco, México, 2007.

[12] L. F. Cervantes, F. González-Montesinos, L. Landa, and B. Sepulveda, "Comparative study of drugs used in the treatment of acute amebic hepatic abscess," Archivos de Investigación Médica, vol. 1, supplement 6, 216 pages, 1970.

[13] G. Gutierrez, J. C. Margain, R. Castaneda, O. Enriquez, M. Aubanel, and B. Sepulveda, "National serologic survey. I. Study of antibodies against E. histolytica in a semirural locality on the Gulf of Mexico Coast," Archivos de Investigación Médica, vol. 5, supplement 2, pp. 475-480, 1974.

[14] G. Gutiérrez, A. Ludlow, G. Espinoza, et al., "Antibodies against Entamoeba histolytica in the Mexican Republic. 1974," Salud Publica de Mexico, vol. 34, no. 2, pp. 242-254, 1992.

[15] L. Landa, M. Aubanel, E. Segovia, and B. Sepúlveda, "Seroepidemiology of amebiasis in adults," Archivos de Investigación Médica, vol. 2, supplement 80, pp. 377-380, 1972.

[16] A. Perches, R. Kretschmer, E. Lee, and B. Sepulveda, "Determination of immunoglobulins in serum from patients with invasive amebiasis," Archivos de Investigación Médica, vol. 1, supplement 100, 1970.

[17] G. M. Ruiz-Palacios, G. Castanon, R. Bojalil, et al., "Low risk of invasive amebiasis in cyst carriers. A longitudinal molecular seroepidemiological study," Archives of Medical Research, vol. 23, no. 2, pp. 289-291, 1992.

[18] M. A. Rodríguez, M. Báez-Camargo, D. M. Delgadillo, and E. Orozco, "Cloning and expression of an Entamoeba histolytica $\mathrm{NADP}^{+}(-)$dependent alcohol dehydrogenase gene," Biochimica et Biophysica Acta, vol. 1306, no. 1, pp. 23-26, 1996.

[19] M. A. Rodríguez, M. E. Hidalgo, T. Sanchez, and E. Orozco, "Cloning and characterization of the Entamoeba histolytica pyruvate: ferredoxin oxidoreductase gene," Molecular and Biochemical Parasitology, vol. 78, no. 1-2, pp. 273-277, 1996.

[20] C. López-Camarillo, M. de la Luz García-Hernández, L. A. Marchat, et al., "Entamoeba histolytica EhDEAD1 is a conserved DEAD-box RNA helicase with ATPase and ATPdependent RNA unwinding activities," Gene, vol. 414, no. 12, pp. 19-31, 2008.

[21] M. G. Meléndez-Hernández, M. L. L. Barrios, E. Orozco, and J. P. Luna-Arias, "The Vacuolar ATPase from Entamoeba histolytica: molecular cloning of the gene encoding for the B subunit and subcellular localization of the protein," BMC Microbiology, vol. 8, article 235, 2008.

[22] E. Orozco, C. López, C. Gomez, D. G. Perez, L. Marchat, C. Bañuelos, and D. M. Delgadillo, "Multidrug resistance in the protozoan parasite Entamoeba histolytica," Parasitology International, vol. 51, no. 4, pp. 353-359, 2002.

[23] R. Arroyo and E. Orozoco, "Localization and identification of an Entamoeba histolytica adhesin," Molecular and Biochemical Parasitology, vol. 23, no. 2, pp. 151-158, 1987.

[24] G. García-Rivera, M. A. Rodríguez, R. Ocádiz, et al., "Entamoeba histolytica: a novel cysteine protease and an adhesin form the $112 \mathrm{kDa}$ surface protein," Molecular Microbiology, vol. 33, no. 3, pp. 556-568, 1999.

[25] C. Martínez-López, E. Orozco, T. Sánchez, R. M. GarcíaPérez, F. Hernandez-Hernandez, and M. A. Rodríguez, "The EhADH112 recombinant polypeptide inhibits cell destruction and liver abscess formation by Entamoeba histolytica trophozoites," Cellular Microbiology, vol. 6, no. 4, pp. 367376, 2004. 
[26] B. Sepulveda, M. Tanimoto-tweki, P. Calderon, and R. de la $\mathrm{Hoz}$, "Neutralization of the virulence of E. histolytica cultures with immune serums," Archivos de Investigación Médica, vol. 5, supplement 2, pp. 447-450, 1974.

[27] B. Sepulveda, M. Tanimoto-tweki, P. Calderon, and R. de la $\mathrm{Hoz}$, "Induction of antiamebic passive immunity in hamsters by injecting immune serum," Archivos de Investigación Médica, vol. 5, supplement 2, pp. 451-456, 1974.

[28] M. Lopez-Osuna, J. Arellano, and R. R. Kretschmer, "The destruction of virulent Entamoeba histolytica by activated human eosinophils," Parasite Immunology, vol. 14, no. 6, pp. 579-586, 1992.

[29] J. R. Velázquez, P. Llaguno, J. Fernández-Diéz, et al., “Antigen induced eosinophilia protects gerbils (Meriones unguiculatus) against experimental amebic abscess of the liver," Archives of Medical Research, vol. 26, pp. S93-S98, 1995.

[30] M. Shibayama, V. Rivera-Aguilar, E. Barbosa-Cabrera, et al., "Innate immunity prevents tissue invasion by Entamoeba histolytica," Canadian Journal of Microbiology, vol. 54, no. 12, pp. 1032-1042, 2008.

[31] R. A. Salata, A. Martinez-Palomo, and H. W. Murray, "Patients treated for amebic liver abscess develop cellmediated immune responses effective in vitro against Entamoeba histolytica," Journal of Immunology, vol. 136, no. 7, pp. 2633-2639, 1986.

[32] R. Kretschmer, M. L. Collado, and M. G. Pacheco, "Inhibition of human monocyte locomotion by products of axenically grown E. histolytica," Parasite Immunology, vol. 7, no. 5, pp. 527-543, 1985.

[33] R. R. Kretschmer, G. Rico, and J. A. Giménez, "A novel anti-inflammatory oligopeptide produced by Entamoeba histolytica," Molecular and Biochemical Parasitology, vol. 112, no. 2, pp. 201-209, 2001.

[34] D. Utrera-Barillas, J. R. Velazquez, A. Enciso, et al., "An anti-inflammatory oligopeptide produced by Entamoeba histolytica down-regulates the expression of pro-inflammatory chemokines," Parasite Immunology, vol. 25, no. 10, pp. 475482, 2003.

[35] S. Rojas-Dotor, G. Rico, J. Perez, et al., "Cytokine expression in $\mathrm{CD}^{+}$cells exposed to the monocyte locomotion inhibitory factor produced by Entamoeba histolytica," Parasitology Research, vol. 98, no. 5, pp. 493-495, 2006.

[36] J. A. Gimenez-Scherer, G. Cardenas, M. Lopez-Osuna, et al., "Immunization with a tetramer derivative of an antiinflammatory pentapeptide produced by Entamoeba histolytica protects gerbils (Meriones unguiculatus) against experimental amoebic abscess of the liver," Parasite Immunology, vol. 26, no. 8-9, pp. 343-349, 2004.

[37] C. Galanos, O. Lüderitz, and O. Westphal, "A new method for the extraction of R lipopolysaccharides," European Journal of Biochemistry, vol. 9, no. 2, pp. 245-249, 1969.

[38] C. Galanos, E. T. Rietschel, O. Lüderitz, O. Westphal, Y. B. Kim, and D. W. Watson, "Biological activities of lipid A complexed with bovine-serum albumin.," European Journal of Biochemistry, vol. 31, no. 2, pp. 230-233, 1972.

[39] C. Galanos, V. Lehmann, and O. Luderitz, "Endotoxic properties of chemically synthesized lipid A structures. Comparison of synthetic lipid A precursor and synthetic analogues with biosynthetic lipid A precursor and free lipid A," European Journal of Biochemistry, vol. 140, no. 2, pp. 221227, 1984.

[40] M. K. Hoffmann, C. Galanos, S. Koenig, and H. F. Oettgen, "B-cell activation by lipopolysaccharide. Distinct pathways for induction of mitosis and antibody production," Journal of Experimental Medicine, vol. 146, no. 6, pp. 1640-1647, 1977.

[41] O. Luderitz, C. Galanos, and V. Lehmann, "Lipid A: chemical structure and biological activity," Journal of Infectious Diseases, vol. 128, supplement, pp. S17-S29, 1973.

[42] O. Lüderitz, C. Galanos, V. Lehmann, H. Mayer, E. T. Rietschel, and J. Weckesser, "Chemical structure and biological activities of lipid A's from various bacterial families," Naturwissenschaften, vol. 65, no. 11, pp. 578-585, 1978.

[43] E. T. Rietschel, Y. B. Kim, D. W. Watson, C. Galanos, O. Luderitz, and O. Westphal, "Pyrogenicity and immunogenicity of lipid A complexed with bovine serum albumin or human serum albumin," Infection and Immunity, vol. 8, no. 2, pp. 173-177, 1973.

[44] K. I. Tanamoto, U. Zahringer, and G. R. McKenzie, "Biological actitivies of synthetic Lipid A analogs: pyrogenicity, lethal toxicity, anticomplement activity, and induction of gelation of Limulus amoebocyte lysate," Infection and Immunity, vol. 44, no. 2, pp. 421-426, 1984.

[45] A. Isibasi, C. M. Santa, A. Ramirez, and J. Kumate, "Immunochemistry of a lipopeptidophosphoglycan extracted from trophozoites of Entamoeba histolytica strain HK-9 cultivated in axenic media, using the phenol-water method," Archivos de Investigación Médica, vol. 13, supplement 3, pp. 51-55, 1982.

[46] A. Isibasi, C. M. Santa, M. Soto, A. Ramirez, and J. Kumate, "Localization of a lipopeptidophosphoglycan extracted by phenol-water from trophozoites of the HK-9 strain of Entamoeba histolytica," Archivos de Investigación Médica, vol. 13, Supplement 3, pp. 57-62, 1982.

[47] G. Acosta, C. Barranco, A. Isibasi, R. Campos, and J. Kumate, "Excretion of anti-ameba specific antibodies of class IgA in bile from rats immunized with trophozoites of Entamoeba histolytica cultivated in axenic media," Archivos de Investigación Médica, vol. 13, Supplement 3, pp. 255-259, 1982.

[48] G. Acosta-Altamirano, E. Torres-Sánchez, E. Meraz, A. Isibasi-Araujo, and J. Kumate-Rodríguez, "Detection of class IgA antibodies directed against a lipopeptidophosphoglycan of E. histolytica in samples of human colostrum," Archivos de Investigaciósn Médica, vol. 17, supplement 1, pp. 291-295, 1986.

[49] R. Campos Rodríguez, C. Barranco-Tovar, A. Isibasi-Araujo, and J. Kumate-Rodríguez, "Anti-amebic plasma cells in peripheral blood of patients with amebic liver abscess," Archivos de Investigación Médica, vol. 17, supplement 1, pp. 303-306, 1986.

[50] C. Agundis, A. Isibasi, V. Oríz, et al., “Obtaining monoclonal antibodies against outer membrane glycoproteins of Entamoeba histolytica," Archivos de Investigación Médica, vol. 21, supplement 1, pp. 15-22, 1990.

[51] A. Bhattacharya, R. Ghildyal, S. Bhattacharya, and L. S. Diamond, "Characterization of a monoclonal antibody that selectively recognizes a subset of Entamoeba histolytica isolates," Infection and Immunity, vol. 58, no. 10, pp. 34583461, 1990.

[52] A. Marinets, T. Zhang, N. Guillén, et al., "Protection against invasive amebiasis by a single monoclonal antibody directed against a lipophosphoglycan antigen localized on the surface of Entamoeba histolytica," Journal of Experimental Medicine, vol. 186, no. 9, pp. 1557-1565, 1997.

[53] Y. C. Yau, I. Crandall, and K. C. Kain, "Development of monoclonal antibodies which specifically recognize Entamoeba histolytica in preserved stool samples," Journal of Clinical Microbiology, vol. 39, no. 2, pp. 716-719, 2001. 
[54] S. I. Miller, R. K. Ernst, and M. W. Bader, "LPS, TLR4 and infectious disease diversity," Nature Reviews Microbiology, vol. 3, no. 1, pp. 36-46, 2005.

[55] N. Burdin, L. Brossay, Y. Koezuka, et al., "Selective ability of mouse CD1 to present glycolipids: alpha-galactosylceramide specifically stimulates V alpha 14+ NK T lymphocytes," Journal of Immunology, vol. 161, no. 7, pp. 3271-3281, 1998.

[56] M. Aubanel, M. Torre-Robles, and B. Sepúlveda, "Trophozoites of Entamoeba histolytica in material from patients with liver abscess," Archivos de Investigación Médica, vol. 1, supplement, 30 pages, 1970.

[57] C. G. Clark, U. C. M. Alsmark, M. Tazreiter, et al., "Structure and content of the Entamoeba histolytica genome," Advances in Parasitology, vol. 65, no. 2, pp. 51-190, 2007.

[58] H. Lotter, N. González-Roldán, B. Lindner, et al., "Natural killer T cells activated by a lipopeptidophosphoglycan from Entamoeba histolytica are critically important to control amebic liver abscess," PLoS Pathogens, vol. 5, no. 5, Article ID e1000434, 2009.

[59] B. Beutler and E. Th. Rietschel, "Innate immune sensing and its roots: the story of endotoxin," Nature Reviews Immunology, vol. 3, no. 2, pp. 169-176, 2003.

[60] A. Coutinho, L. Forni, F. Melchers, and T. Watanabe, "Genetic defect in responsiveness to the B cell mitogen lipopolysaccharide," European Journal of Immunology, vol. 7, no. 5, pp. 325-328, 1977.

[61] G. Heppner and D. W. Weiss, "High susceptibility of strain A mice to endotoxin and endotoxin-red blood cell mixtures," Journal of Bacteriology, vol. 90, no. 3, pp. 696-703, 1965.

[62] A. Poltorak, X. He, I. Smirnova, et al., "Defective LPS signaling in $\mathrm{C} 3 \mathrm{H} / \mathrm{HeJ}$ and $\mathrm{C} 57 \mathrm{BL} / 10 \mathrm{ScCr}$ mice: mutations in Tlr4 gene," Science, vol. 282, no. 5396, pp. 2085-2088, 1998.

[63] C. Hashimoto, K. L. Hudson, and K. V. Anderson, "The Toll gene of drosophila, required for dorsal-ventral embryonic polarity, appears to encode a transmembrane protein," Cell, vol. 52, no. 2, pp. 269-279, 1988.

[64] B. Lemaitre, E. Nicolas, L. Michaut, J.-M. Reichhart, and J. A. Hoffmann, "The dorsoventral regulatory gene cassette spatzle/Toll/Cactus controls the potent antifungal response in Drosophila adults," Cell, vol. 86, no. 6, pp. 973-983, 1996.

[65] F. L. Rock, G. Hardiman, J. C. Timans, R. A. Kastelein, and J. F. Bazan, "A family of human receptors structurally related to Drosophila Toll," Proceedings of the National Academy of Sciences of the United States of America, vol. 95, no. 2, pp. 588593, 1998.

[66] R. Medzhitov, P. Preston-Hurlburt, and C. A. Janeway Jr., "A human homologue of the Drosophila toll protein signals activation of adaptive immunity," Nature, vol. 388, no. 6640, pp. 394-397, 1997.

[67] K. J. Ishii, C. Coban, and S. Akira, "Manifold mechanisms of toll-like receptor-ligand recognition," Journal of Clinical Immunology, vol. 25, no. 6, pp. 511-521, 2005.

[68] K. J. Ishii, S. Koyama, A. Nakagawa, C. Coban, and S. Akira, "Host innate immune receptors and beyond: making sense of microbial infections," Cell Host and Microbe, vol. 3, no. 6, pp. 352-363, 2008.

[69] B. Pulendran and R. Ahmed, "Translating innate immunity into immunological memory: implications for vaccine development," Cell, vol. 124, no. 4, pp. 849-863, 2006.

[70] C. A. Janeway Jr., "Approaching the asymptote? Evolution and revolution in immunology," Cold Spring Harbor Symposia on Quantitative Biology, vol. 54, part 1, pp. 1-13, 1989.

[71] R. T. Gazzinelli and E. Y. Denkers, "Protozoan encounters with Toll-like receptor signalling pathways: implications for host parasitism," Nature Reviews Immunology, vol. 6, no. 12, pp. 895-906, 2006.

[72] M. J. McConville and M. A. J. Ferguson, "The structure, biosynthesis and function of glycosylated phosphatidylinositols in the parasitic protozoa and higher eukaryotes," Biochemical Journal, vol. 294, part 2, pp. 305-324, 1993.

[73] A. Guha-Niyogi, D. R. Sullivan, and S. J. Turco, "Glycoconjugate structures of parasitic protozoa," Glycobiology, vol. 11, no. 4, pp. 45R-59R, 2001.

[74] M. J. de Veer, J. M. Curtis, T. M. Baldwin, et al., "MyD88 is essential for clearance of Leishmania major: possible role for lipophosphoglycan and Toll-like receptor 2 signaling," European Journal of Immunology, vol. 33, no. 10, pp. 28222831, 2003.

[75] I. Becker, N. Salaiza, M. Aguirre, et al., "Leishmania lipophosphoglycan (LPG) activates NK cells through toll-like receptor-2," Molecular and Biochemical Parasitology, vol. 130, no. 2, pp. 65-74, 2003.

[76] G. Krishnegowda, A. M. Hajjar, J. Zhu, et al., "Induction of proinflammatory responses in macrophages by the glycosylphosphatidylinositols of Plasmodium falciparum: cell signaling receptors, glycosylphosphatidylinositol (GPI) structural requirement, and regulation of GPI activity," Journal of Biological Chemistry, vol. 280, no. 9, pp. 86068616, 2005.

[77] F. P. Mockenhaupt, J. P. Cramer, and L. Hamann, "Tolllike receptor (TLR) polymorphisms in African children: common TLR-4 variants predispose to severe malaria," Journal of Communicable Diseases, vol. 38, no. 3, pp. 230-245, 2006.

[78] D. C. Gowda, "TLR-mediated cell signaling by malaria GPIs," Trends in Parasitology, vol. 23, no. 12, pp. 596-604, 2007.

[79] C. Ropert, B. S. Franklin, and R. T. Gazzinelli, "Role of TLRs/MyD88 in host resistance and pathogenesis during protozoan infection: lessons from malaria," Seminars in Immunopathology, vol. 30, no. 1, pp. 41-51, 2008.

[80] R. M. de Lederkremer, C. Lima, M. I. Ramirez, M. A. J. Ferguson, S. W. Homans, and J. Thomas-Oates, "Complete structure of the glycan of lipopeptidophosphoglycan from Trypanosoma cruzi epimastigotes," Journal of Biological Chemistry, vol. 266, no. 35, pp. 23670-23675, 1991.

[81] M. A. S. Campos, I. C. Almeida, O. Takeuchi, et al., "Activation of toll-like receptor-2 by glycosylphosphatidylinositol anchors from a protozoan parasite," Journal of Immunology, vol. 167, no. 1, pp. 416-423, 2001.

[82] A. Bafica, H. C. Santiago, R. Goldszmid, C. Ropert, R. T. Gazzinelli, and A. Sher, "Cutting edge: TLR9 and TLR2 signaling together account for MyD88-dependent control of parasitemia in Trypanosoma cruzi infection," Journal of Immunology, vol. 177, no. 6, pp. 3515-3519, 2006.

[83] A. Ouaissi, E. Guilvard, Y. Delneste, et al., “The Trypanosoma cruzi Tc52-released protein induces human dendritic cell maturation, signals via Toll-like receptor 2, and confers protection against lethal infection," Journal of Immunology, vol. 168, no. 12, pp. 6366-6374, 2002.

[84] F. Debierre-Grockiego, N. Molitor, R. T. Schwarz, and C. G. K. Lüder, "Toxoplasma gondii glycosylphosphatidylinositols up-regulate major histocompatibility complex (MHC) molecule expression on primary murine macrophages," Innate Immunity, vol. 15, no. 1, pp. 25-32, 2009.

[85] C. Maldonado-Bernal, C. J. Kirschning, Y. Rosenstein, et al., "The innate immune response to Entamoeba histolytica lipopeptidophosphoglycan is mediated by toll-like receptors 2 and 4," Parasite Immunology, vol. 27, no. 4, pp. 127-137, 2005. 
[86] F. Debierre-Grockiego, M. A. Campos, N. Azzouz, et al., "Activation of TLR2 and TLR4 by glycosylphosphatidylinositols derived from Toxoplasma gondii," Journal of Immunology, vol. 179, no. 2, pp. 1129-1137, 2007.

[87] D. van der Kleij, E. Latz, J. F. H. M. Brouwers, et al., "A novel host-parasite lipid cross-talk. Schistosomal lysophosphatidylserine activates toll-like receptor 2 and affects immune polarization," Journal of Biological Chemistry, vol. 277, no. 50, pp. 48122-48129, 2002.

[88] A.-C. Oliveira, J. R. Peixoto, L. B. De Arrada, et al., "Expression of functional TLR4 confers proinflammatory responsiveness to Trypanosoma cruzi glycoinositolphospholipids and higher resistance to infection with T. cruzi," Journal of Immunology, vol. 173, no. 9, pp. 5688-5696, 2004.

[89] H. S. Goodridge, F. A. Marshall, K. J. Else, et al., "Immunomodulation via novel use of TLR4 by the filarial nematode phosphorylcholine-containing secreted product, ES-62," Journal of Immunology, vol. 174, no. 1, pp. 284-293, 2005.

[90] P. G. Thomas, M. R. Carter, O. Atochina, et al., "Maturation of dendritic cell 2 phenotype by a helminth glycan uses a Toll-like receptor 4-dependent mechanism," Journal of Immunology, vol. 171, no. 11, pp. 5837-5841, 2003.

[91] C. Coban, K. J. Ishii, T. Kawai, et al., "Toll-like receptor 9 mediates innate immune activation by the malaria pigment hemozoin," Journal of Experimental Medicine, vol. 201, no. 1, pp. 19-25, 2005.

[92] L. K. M. Shoda, K. A. Kegerreis, C. E. Suarez, et al., "DNA from protozoan parasites Babesia bovis, Trypanosoma cruzi, and $\mathrm{T}$. brucei is mitogenic for B lymphocytes and stimulates macrophage expression of interleukin-12, tumor necrosis factor alpha, and nitric oxide," Infection and Immunity, vol. 69, no. 4, pp. 2162-2171, 2001.

[93] F. H. Abou Fakher, N. Rachinel, M. Klimczak, J. Louis, and N. Doyen, "TLR9-dependent activation of dendritic cells by DNA from Leishmania major favors Th1 cell development and the resolution of lesions," Journal of immunology, vol. 182, no. 3, pp. 1386-1396, 2009.

[94] C. P. A. Ivory, M. Prystajecky, C. Jobin, and K. Chadee, "Toll-like receptor 9-dependent macrophage activation by Entamoeba histolytica DNA," Infection and Immunity, vol. 76, no. 1, pp. 289-297, 2008.

[95] F. Yarovinsky, D. Zhang, J. F. Andersen, et al., "Immunology: TLR11 activation of dendritic cells by a protozoan profilinlike protein," Science, vol. 308, no. 5728, pp. 1626-1629, 2005.

[96] C. Maldonado, W. Trejo, A. Ramirez, et al., "Lipophosphopeptidoglycan of Entamoeba histolytica induces an antiinflammatory innate immune response and downregulation of toll-like receptor 2 (TLR-2) gene expression in human monocytes," Archives of Medical Research, vol. 31, no. 4, supplement 1, pp. S71-S73, 2000.

[97] H. Vivanco-Cid, C. Alpuche-Aranda, I. Wong-Baeza, et al., "Lipopopeptidephosphoglycan from Entamoeba histolytica activates human macrophages and dendritic cells and reaches their late endosomes," Parasite Immunology, vol. 29, no. 9, pp. 467-474, 2007.

[98] W. A. Petri Jr. and R. L. Schnaar, "Purification and characterization of galactose- and $\mathrm{N}$ - acetylgalactosaminespecific adhesin lectin of Entamoeba histolytica," Methods in Enzymology, vol. 253, pp. 98-104, 1995.

[99] J. L. Rosales-Encina, I. Meza, A. Lopez-De-Leon, P. TalamasRohana, and M. Rojkind, "Isolation of a 220-kilodalton protein with lectin properties from a virulent strain of Entamoeba histolytica," Journal of Infectious Diseases, vol. 156, no. 5, pp. 790-797, 1987.
[100] S. L. Stanley Jr., H. Huizenga, and E. Li, "Isolation and partial characterization of a surface glycoconjugate of Entamoeba histolytica," Molecular and Biochemical Parasitology, vol. 50, no. 1, pp. 127-138, 1992.

[101] D. R. Boettner, C. D. Huston, J. A. Sullivan, and W. A. Petri Jr., "Entamoeba histolytica and Entamoeba dispar utilize externalized phosphatidylserine for recognition and phagocytosis of erythrocytes," Infection and Immunity, vol. 73, no. 6, pp. 3422-3430, 2005.

[102] E. E. Avila and J. Calderon, "Entamoeba histolytica trophozoites: a surface-associated cysteine protease," Experimental Parasitology, vol. 76, no. 3, pp. 232-241, 1993.

[103] T. Jacobs, I. Bruchhaus, T. Dandekar, E. Tannich, and M. Leippe, "Isolation and molecular characterization of a surface-bound proteinase of Entamoeba histolytica," Molecular Microbiology, vol. 27, no. 2, pp. 269-276, 1998.

[104] N. Perreault, F. E. Herring-Gillam, N. Desloges, I. Bélanger, L.-P. Pageot, and J.-F. Beaulieu, "Epithelial vs mesenchymal contribution to the extracellular matrix in the human intestine," Biochemical and Biophysical Research Communications, vol. 248, no. 1, pp. 121-126, 1998.

[105] S. L. Reed, W. E. Keene, and J. H. McKerrow, "Thiol proteinase expression and pathogenicity of Entamoeba histolytica," Journal of Clinical Microbiology, vol. 27, no. 12, pp. 2772-2777, 1989.

[106] H. Scholze and W. Schulte, "On the specificity of a cysteine proteinase from Entamoeba histolytica," Biomedica Biochimica Acta, vol. 47, no. 2, pp. 115-123, 1988.

[107] H. Scholze and E. Tannich, "Cysteine endopeptidases of Entamoeba histolytica," Methods in Enzymology, vol. 244, pp. 512-523, 1994.

[108] W. Schulte and H. Scholze, "Action of the major protease from Entamoeba histolytica on proteins of the extracellular matrix," Journal of Protozoology, vol. 36, no. 6, pp. 538-543, 1989.

[109] M. Espinosa-Cantellano and A. Martínez-Palomo, "Pathogenesis of intestinal amebiasis: from molecules to disease," Clinical Microbiology Reviews, vol. 13, no. 2, pp. 318-331, 2000.

[110] A. Martinez-Palomo and M. Espinosa-Cantellano, "Amoebiasis: new understanding and new goals," Parasitology Today, vol. 14, no. 1, pp. 1-3, 1998.

[111] M. Okada and T. Nozaki, "New insights into molecular mechanisms of phagocytosis in Entamoeba histolytica by proteomic analysis," Archives of Medical Research, vol. 37, no. 2, pp. 244-252, 2006.

[112] A. E. Pinilla, M. C. López, and D. F. Viasus, "History of the Entamoeba histolytica protozoan," Revista Médica de Chile, vol. 136, no. 1, pp. 118-124, 2008.

[113] K. Prathap and R. Gilman, "The histopathology of acute intestinal amebiasis. A rectal biopsy study.", American Journal of Pathology, vol. 60, no. 2, pp. 229-246, 1970.

[114] M. E. Quintanar-Quintanar, A. Jarillo-Luna, V. RiveraAguilar, et al., "Immunosuppressive treatment inhibits the development of amebic liver abscesses in hamsters," Medical Science Monitor, vol. 10, no. 9, pp. BR317-BR324, 2004.

[115] V. Tsutsumi, R. Mena-Lopez, F. Anaya-Velazquez, and A. Martinez-Palomo, "Cellular bases of experimental amebic liver abscess formation," American Journal of Pathology, vol. 117, no. 1, pp. 81-91, 1984.

[116] M. De Lourdes Canales-Trevino, V. Tsutsumi, and A. Martinez-Palomo, "Role of macrophages and Tlymphocytes: resistance of guinea pigs to amebic liver infection," Archivos de Investigación Médica, vol. 21, supplement 1, pp. 81-84, 1990. 
[117] V. Tsutsumi and M. Shibayama, "Experimental amebiasis: a selected review of some in vivo models," Archives of Medical Research, vol. 37, no. 2, pp. 210-220, 2006.

[118] S. J. Kammanadiminti, B. J. Mann, L. Dutil, and K. Chadee, "Regulation of Toll-like receptor-2 expression by the Gallectin of Entamoeba histolytica," The FASEB Journal, vol. 18, no. 1, pp. 155-157, 2004.

[119] D. Vats, R. A. Vishwakarma, S. Bhattacharya, and A. Bhattacharya, "Reduction of cell surface glycosylphosphatidylinositol conjugates in Entamoeba histolytica by antisense blocking of E. histolytica GlcNAc-phosphatidylinositol deacetylase expression: effect on cell proliferation, endocytosis, and adhesion to target cells," Infection and Immunity, vol. 73, no. 12, pp. 8381-8392, 2005.

[120] Z. Zhang, M. Duchêne, and S. L. Stanley Jr., "A monoclonal antibody to the amebic lipophosphoglycanproteophosphoglycan antigens can prevent disease in human intestinal xenografts infected with Entamoeba histolytica," Infection and Immunity, vol. 70, no. 10, pp. 5873-5876, 2002.

[121] S. Moody, S. Becker, Y. Nuchamowitz, and D. Mirelman, "Virulent and avirulent Entamoeba histolytica and E. dispar differ in their cell surface phosphorylated glycolipids," Parasitology, vol. 114, part 2, pp. 95-104, 1997.

[122] L. Van Kaer and S. Joyce, "Innate immunity: NKT cells in the spotlight," Current Biology, vol. 15, no. 11, pp. R429-R431, 2005.

[123] D. Zhou, J. Mattner, C. Cantu III, et al., "Lysosomal glycosphingolipid recognition by NKT cells," Science, vol. 306, no. 5702, pp. 1786-1789, 2004.

[124] J. Mattner, K. L. DeBord, N. Ismail, et al., "Exogenous and endogenous glycolipid antigens activate NKT cells during microbial infections," Nature, vol. 434, no. 7032, pp. 525529, 2005.

[125] E. Acosta-Ramírez, R. Pérez-Flores, N. Majeau, et al., “Translating innate response into long-lasting antibody response by the intrinsic antigen-adjuvant properties of papaya mosaic virus," Immunology, vol. 124, no. 2, pp. 186-197, 2008.

[126] L. Cervantes-Barragán, C. Gil-Cruz, R. Pastelin-Palacios, et al., "TLR2 and TLR4 signaling shapes specific antibody responses to Salmonella typhi antigens," European Journal of Immunology, vol. 39, no. 1, pp. 126-135, 2009.

[127] I. Secundino, C. López-Macías, L. Cervantes-Barrag án, et al., "Salmonella porins induce a sustained, lifelong specific bactericidal antibody memory response," Immunology, vol. 117, no. 1, pp. 59-70, 2006.

[128] F. Yarovinsky, H. Kanzler, S. Hieny, R. L. Coffman, and A. Sher, "Toll-like receptor recognition regulates immunodominance in an antimicrobial CD $4^{+} \mathrm{T}$ cell response," Immunity, vol. 25, no. 4, pp. 655-664, 2006.

[129] Q. Wang, R. M. McLoughlin, B. A. Cobb, et al., "A bacterial carbohydrate links innate and adaptive responses through Toll-like receptor 2," Journal of Experimental Medicine, vol. 203, no. 13, pp. 2853-2863, 2006.

[130] T. Querec, S. Bennouna, S. Alkan, et al., "Yellow fever vaccine YF-17D activates multiple dendritic cell subsets via TLR2, 7, 8, and 9 to stimulate polyvalent immunity," Journal of Experimental Medicine, vol. 203, no. 2, pp. 413-424, 2006.

[131] M. F. Delgado, S. Coviello, A. C. Monsalvo, et al., "Lack of antibody affinity maturation due to poor Toll-like receptor stimulation leads to enhanced respiratory syncytial virus disease," Nature Medicine, vol. 15, no. 1, pp. 34-41, 2009.

[132] P. Marrack, A. S. McKee, and M. W. Munks, "Towards an understanding of the adjuvant action of aluminium," Nature Reviews Immunology, vol. 9, no. 4, pp. 287-293, 2009.
[133] N. W. Palm and R. Medzhitov, "Immunostimulatory activity of haptenated proteins," Proceedings of the National Academy of Sciences of the United States of America, vol. 106, no. 12, pp. 4782-4787, 2009. 

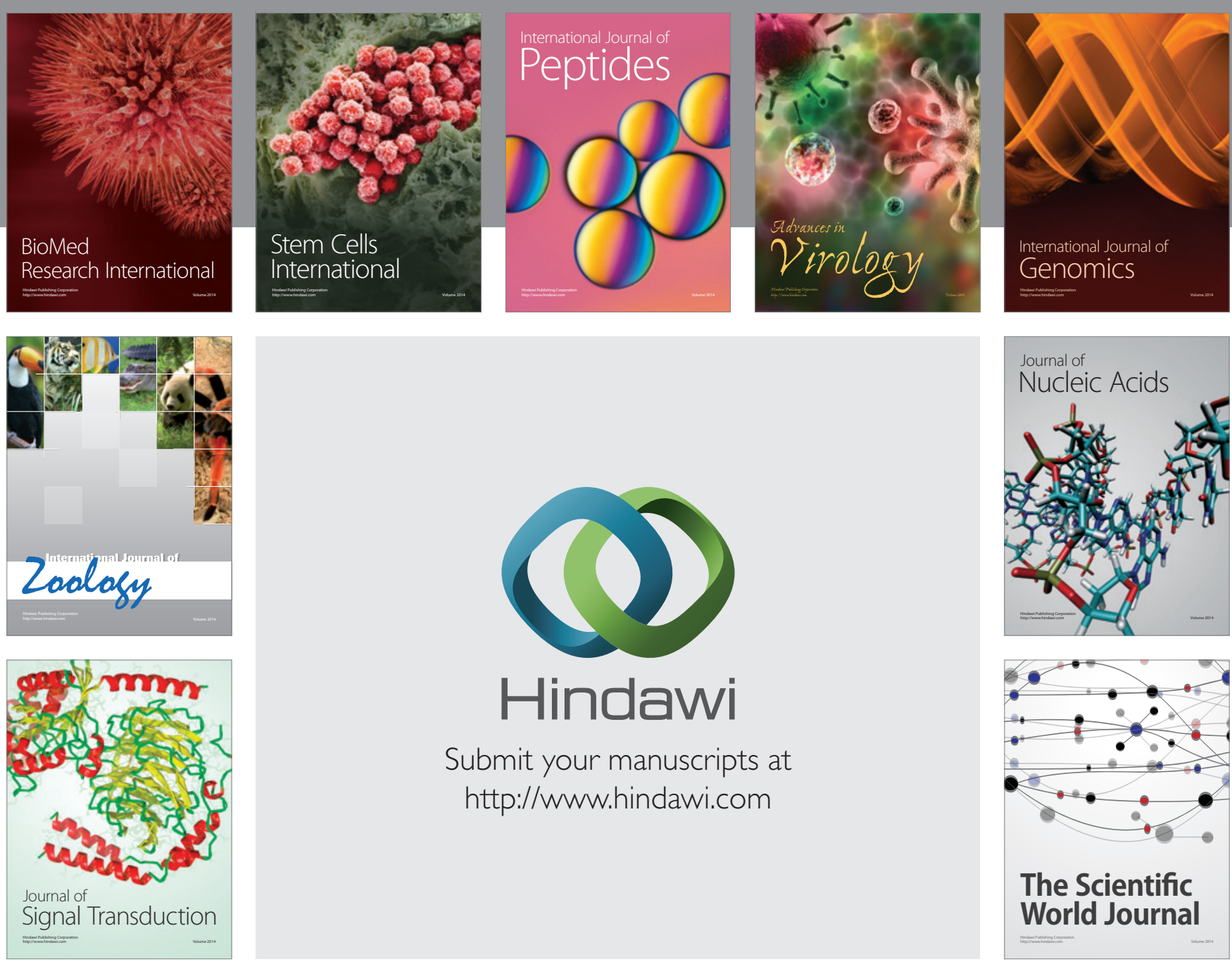

Submit your manuscripts at

http://www.hindawi.com
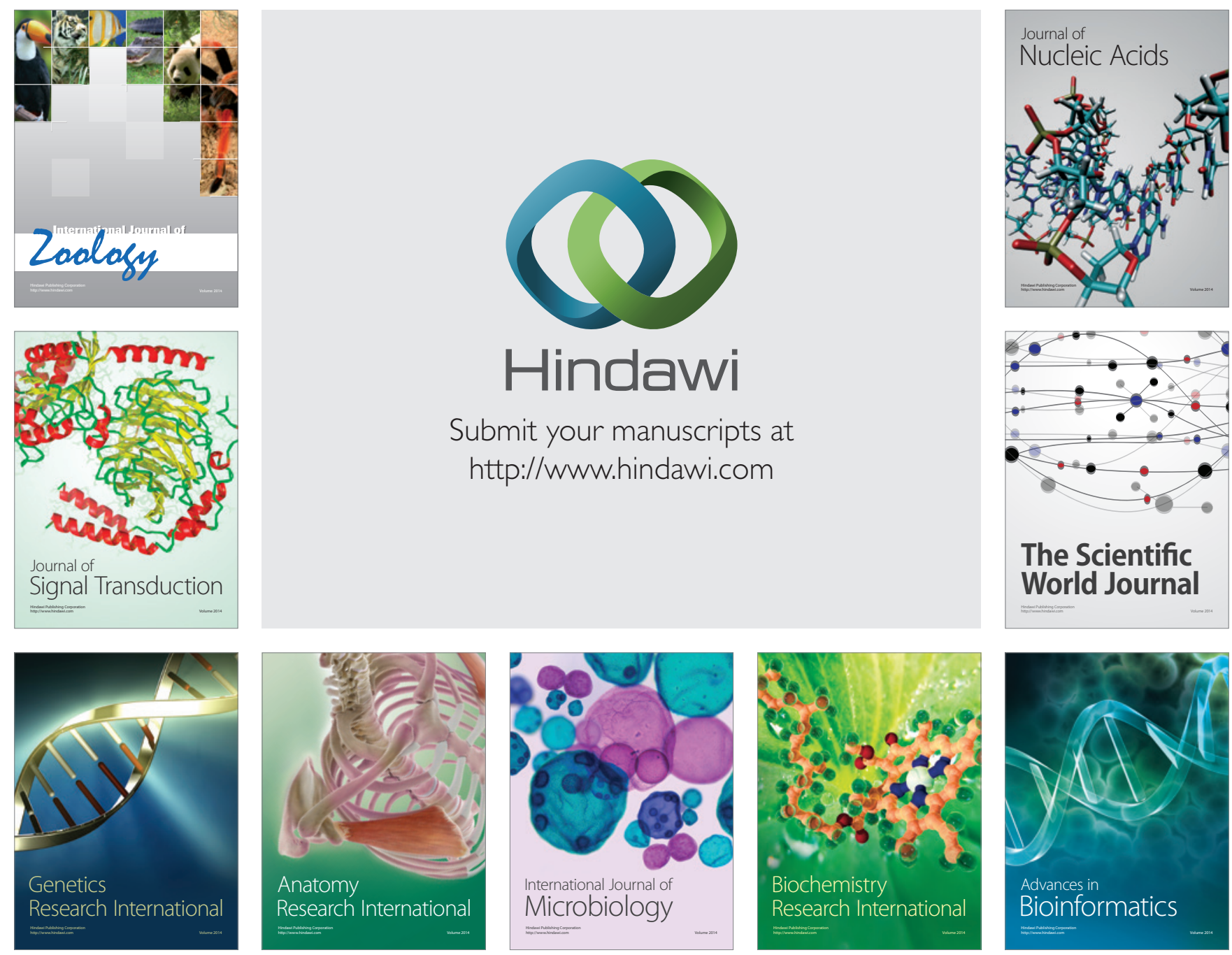

The Scientific World Journal
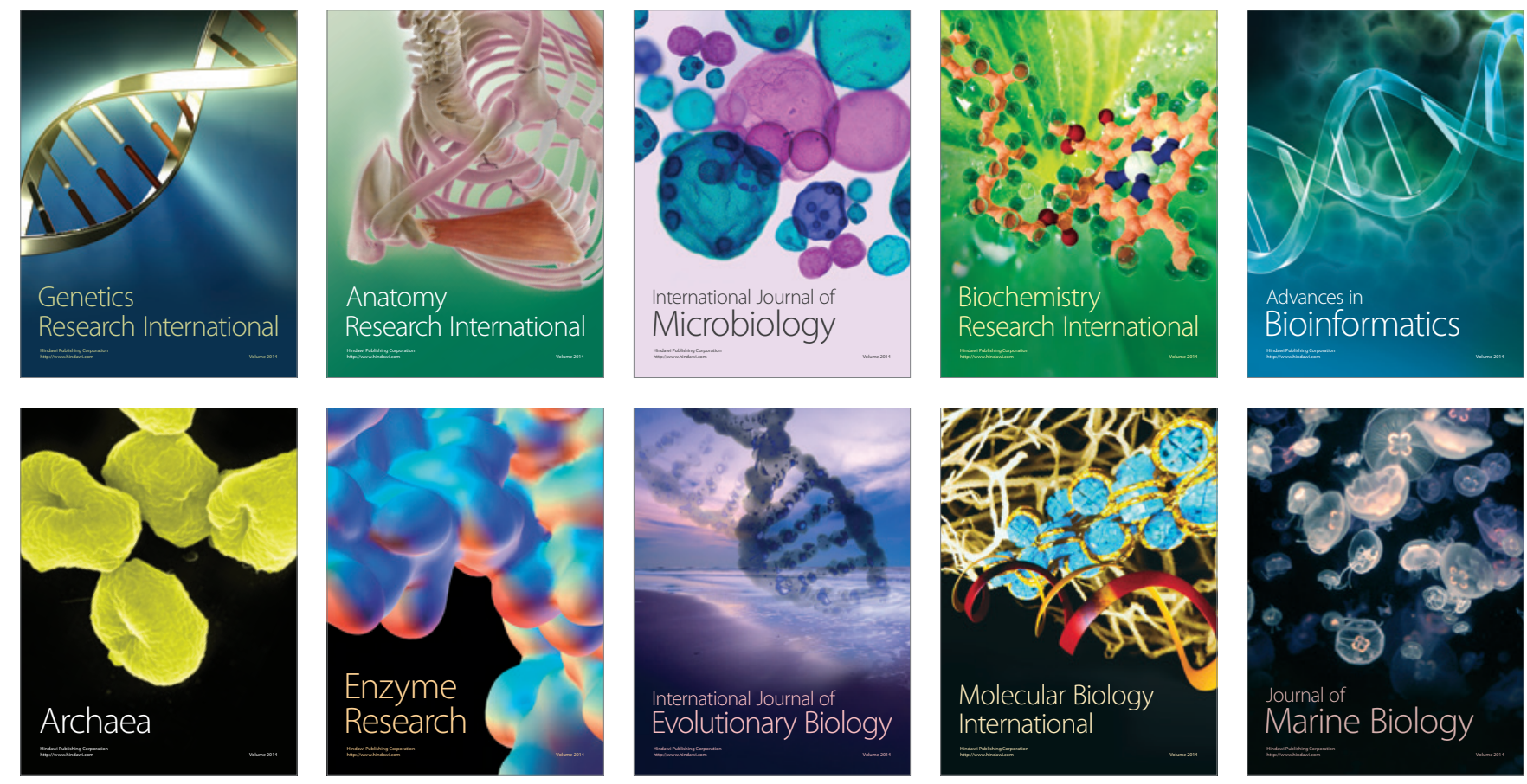